YEARBOOK

of ANTITRUST

and REGULATORY

STUDIES

www.yars.wz.uw.edu.pl
Peer-reviewed scientific periodical, focusing on legal and economic issues of antitrust and regulation. Creative Commons Attribution-No Derivative Works 3.0 Poland License.

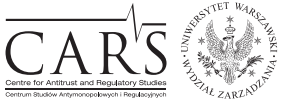

Centre for Antitrust and Regulatory Studies, University of Warsaw, Faculty of Management www.cars.wZ.uw.edu.pl

\title{
New Scenarios of the Right of Defence Following Directive 1/2019
}

\author{
by
}

Marialaura Rea*

\section{CONTENTS}

I. Introduction

II. Background about the adoption of Directive 2019/1

III. Problems and challenges of Article 3 of Directive 2019/1

IV. Right of defence by the European Commission in the context of competition proceedings

1. Right to be informed

2. Right to access the file

3. Privilege against self-incrimination

4 Legal professional privilege

V. Some perspectives for the transposition of Directive 2019/1 - the Italian case

\section{Abstact}

The purpose of this paper is to analyze the effects of Article 3 of Directive 1/2019 when transposing it by Member States. The incompleteness and vagueness of Article 3 of Directive 2019/1 could cause non-harmonization in the various EU Member States, especially those in Eastern Europe, of the right of defence for the defendant party in the antitrust procedure. More specifically, to avoid this effect, Member States must adapt to European standards. In doing so, the paper intends to shed some light on how the right of defence is protected by the European Commission during competition proceedings.

* Ph.D. in Law and Economics, University of Study Naples 'Parthenope'; Stager at the Office of Commissioner Gabriella Muscolo, Italian Competition Authority. Article received: 2 July 2019; accepted: 15 August 2019. 


\section{Résumé}

Le présent article a pour objectif d'analyser les effets de l'article 3 de la directive 1/2019 lors de sa transposition par les États membres. Le caractère incomplet et imprécis de l'article 3 de la directive 1/2019 pourrait provoquer une non-harmonisation dans les différents États membres de l'UE, notamment en Europe orientale, des droits de la défense dans la procédure en matière de concurrence. Plus précisément, pour éviter cet effet, les États membres doivent s'adapter aux normes européennes. Le présent article entend apporter un éclairage sur la manière dont les droits de la défense sont protégés par la Commission européenne dans le cadre des procédures en matière de concurrence.

Key words: right of defence, due process, ECN+ Directive, National Competition Authorities, European Commission.

JEL: K21, K38

\section{Introduction}

This study focuses its attention exclusively on Article 3 of Directive 2019/1 which protects the right of defence in the context of competition proceedings. ${ }^{1}$ Directive 2019/1 pursues the aim of harmonizing the powers and functions of National Competition Authorities in all Member States. However, as it will be shown, the content of Article 3 of Directive 2019/1 is vague and meager, only requiring Member States to ensure respect for fundamental human rights, without being explicit about what rights. As a result, the rule may not be implemented equally in all Member States, as some commentators have suggested. This could cause the failure in achieving the goal of uniformity that the European legislator set with the adoption of Directive 2019/1. It is believed that, in order to avoid this negative outcome, Member States should transpose the Directive by expanding its content. Member States should keep in mind how the right of defence is protected by European rules, how it is applied by the European Commission and how the Court of Justice interprets it.

In this work, we show how it is possible to achieve this objective. For the sake of clarity, this work intends, first of all, to reconstruct the reasons that stimulated the adoption of the Directive (section 2); analyze the problems

${ }^{1}$ European Commission, Directive (EU) 2019/1 of the European Parliament and of the Council of 11 December 2018 to empower the Competition Authorities of the Member States to be more effective enforcers and to ensure the proper functioning of the internal market, Brussels, January 2019. 
and challenges of Article 3 of Directive 2019/1 (section 3); to then reconstruct how the right of defence is protected on the basis of European norms and the jurisprudence of the Court of Justice of the European Union (section 4).

This reconstruction is important, as it highlights which indications the Member States should keep in mind when each of them adopts Directive 2019/1 to avoid creating fragmentation in terms of rights (section 5).

\section{Background about the adoption of Directive 2019/1}

Last 11 December 2018, the European Parliament and the Council have adopted Directive (EU) 2019/1 to empower the Competition Authorities of Member States, so that they can be more effective enforcers and can ensure the proper functioning of the internal market. ${ }^{2}$

The principal aim of Directive 2019/1 is to ensure effective enforcement of Articles 101 and 102 TFEU, in order to guarantee fairer and more open competitive markets in the Union. Ensuring a better efficacy of market competition, it allows companies to compete more on their own merits, avoiding barriers to market entry (Wils 2017). From the consumer's point of view, it protects against artificially high prices of goods and services.

The objective of Directive 2019/1 is to ensure that National Competition Authorities (hereinafter: NCAs) have the guarantees of independence, adequate resources, and fining powers necessary to apply Articles 101 and 102 TFEU. In particular, these guarantees are essential in cases of parallel application of national competition law and EU law (for general overview of the directive, Papp 2019, Assonime 2019, Ghezzi, Marchetti 2017, p. 1015).

Gaps and limitations in the tools and guarantees of NCAs undermine the system of parallel powers for the enforcement of Articles 101 and 102 TFEU, which are designed to work as a cohesive whole based on close cooperation within the European Competition Network. This system doesn't work well when there are still NCAs that do not have adequate fact-finding tools (Pace 2004, p. 147; Pera, Pace 2003, p. 433; Torchia 2006; Brammer 2005, p. 1383;

2 On $30^{\text {th }}$ May 2018, the European Commission published a press release where it indicated that the representatives of the Council and the European Parliament had achieved a political agreement concerning a shared text of the Directive. The legal basis of the Directive is, in fact, Art. 103 and 114 TFEU. Art. 114 TFEU refers to the 'ordinary' decision-making procedure, which requires the positive vote of the Council and the Parliament. European Commission, Commission welcomes political agreement reached by the European Parliament and the Council on new rules making to make national competition authorities even more effective enforcers. The text of the press release is available at: http://europa.eu/rapid/press-release_STATEMENT-18-3996_ en.htm. 
Ortiz Blanco 2006; Türk 2006, p. 215; Wils 2008; Völcker 2004, p. 1027; Gerber 2005; Cengiz 2010, p. 35; D’Alberti; Wilks 2005, p. 431; Guerri 2005).

The last Directive (EU) 2019/1, that changes Regulation (EC) 1/2003, shares with Directive (EU) 2014/104 the goal of ensuring more effective competition through the relationship between public and private enforcement. The European legislator is aware that only empowering the effectiveness of public and private tools can be able to increase economy in the whole European market. ${ }^{3}$

Regarding the purposes which have stimulated the adoption of Directive 2019/1, they are embedded in two documents: one of this is 'Ten years of antitrust enforcement under Regulation 1/2003: achievements and future perspectives'; the other one is 'Co-operation Issues and Due Process'. ${ }^{4}$

In the first of these documents, it was verified that 'Regulation 1/2003 has given the Commission greater scope to set its priorities, enabling it to devote more resources to investigating cases and conducting inquiries in key sectors of the economy suffering from market distortions, as well as less conventional forms of anticompetitive'. ${ }^{5}$ The second one concerns the rules on mutual assistance and cooperation between National Competition Authorities.

\section{Problems and challenges of Article 3 of Directive 2019/1}

Article 3 of Directive 2019/1 concerns the issue of guarantees and, in particular, of the right of defence during the proceedings concerning infringements of Articles 101 and 102 of the TFEU. ${ }^{6}$

The standard has a vague and incomplete content. Because of this, it has been the focus of a debate among academics. In fact, Article 3 of Directive 2019/1

3 European Commission, Directive 2014/104/Eu of the European Parliament and of the Council of 26 November 2014 on certain rules governing actions for damages under national law for infringements of the competition law provisions of the Member States and of the European Union.

${ }^{4}$ European Commission, Communication from the Commission to the European Parliament and the Council - Ten Years of Antitrust Enforcement under Regulation 1/2003: Achievements and Future Perspectives COM (2014) 453. The test is available at: http://ec.europa.eu/competition/ antitrust/legislation/antitrust_enforcement_10_years_en.pdf; European Competition Network, ECN Working Group Cooperation Issues and Due Process Investigative Powers Report, 31 ottobre 2012. The test is available at: http://ec.europa.eu/competition/ecn/investigative_powers_report_ en.pdf.

5 Council Regulation (EC) No 1/2003 of 16.12.2002 on the implementation of the rules on competition laid down in Articles 81 and 82 of the Treaty.

6 Judgment of the European Court of Human Rights (hereinafter: ECtHR) of 10.10.2012, case no. 58331/09 Gregačević v. Croatia, par. 49. 
establishes only in the first paragraph that NCAs must respect the general principles of the European Union and the Charter of Fundamental Rights of the European Union (hereinafter: ECHR). The second paragraph of Article 3 of Directive 2019/1 only adds that the exercise of powers by the Guarantors Authorities is subject to appropriate guarantees, such as the right of defence and the right to an effective remedy before a tribunal (Monti 2018; Botta 2018; Parcu 2018; Denkers 2018; Caragiale 2018).

From what we have just seen, it is clear that the rule is excessively generic, especially taking into account the different institutional formation of the Competition Authorities of the various Member States.

During the preparatory phase of the Directive, many commentators had called for greater attention to the Directive in the part concerning fundamental rights. On this latter point, the Report accompanying the Directive proposal is more specific on the subject of fundamental rights. Indeed, it considers that the companies subject to competition proceedings are granted the right to conduct a business, the right to property, good administration, the right to an effective remedy before a court, and last but not least, the right of defence.

However, the vagueness of Article 3 of Directive 2019/1 puts the objectives of Directive 2019/1 at risk. In fact, the main goal of Directive 2019/1 is a more effective application of competition rules in the Member States. This goal is pursued by Directive 2019/1, giving the same powers and the same rules in all EU Member States (Botta, Svetlicinii 2015, p. 276).

But the lack of Article 3 of Directive 2019/1 could lead to a paradox: NCAs will have equal investigative and sanctioning powers, but the companies during the proceedings concerning infringements of Article 101 e 102 TFEU will not have the same defence rights.

About this issue, a 2018 study investigated how the right of defence is protected in seven different states: Bulgaria, Croatia, Czech Republic, Hungary, Poland, Slovakia and Romania. It emerged from this study that the right of defence in the proceedings before NCAs is not protected equally in the various selected jurisdictions (Bernatt, Botta, Svetlicinii 2018, p. 303).

In all the analyzed jurisdictions, for example, the Statement of Objections sent to the defendant, indicating the contested violations, and the right to be informed is equally protected.

A certain degree of convergence on the right to be informed and access to the file is guaranteed in all Member States; by contrast, the privilege against self-incrimination and the legal professional privilege are applied in a divergent way in the selected jurisdictions. ${ }^{7}$

7 European Commission, Notice on best practices for the conduct of proceedings concerning Articles 101 and 102 TFEU. Para. 109-112. 
In particular, the privilege against self-incrimination is not guaranteed in five of the six analyzed countries: Bulgaria, Croatia, Hungary, Poland, Slovakia and Romania. Only the Czech Republic recognizes the privilege against self-incrimination. Furthermore, the selected jurisdictions do not directly extend such privilege in the relevant statutes to legal persons involved in administrative proceedings for a violation of competition law.

In accordance with the above, this research study demonstrates the state of disparity between the various Member States regarding the right of defence. For this reason, Article 3 of Directive 2019/1 must be interpreted in the light of the jurisprudence of the Court of Justice European Union and the rules applicable by the European Commission in relation to the right of defence.

\section{Right of defence by the European Commission in the context of competition proceedings}

The right to defence is one of the most important fundamental rights and components of justice. In fact, some authors argue that the right to defence in not a simple bundle of procedural guarantees (Michałek 2015). This right can be divided into four sub-rights: i) right to be informed; ii) right to access the file; iii) privilege against self-incrimination; iv) legal professional privilege.

\section{Right to be informed}

The Commission must comply with general principles of EU law, which include inter alia respecting the rights of defence during administrative proceedings. The right to be informed is instrumental to the exercise of the right to be heard. ${ }^{8}$

8 According to Italian legislation, the right to be informed during the administrative procedure is protected by Articles 7 and 10bis of the Lex no. 241/1990. Article no. 7 states '1. Ove non sussistano ragioni di impedimento derivanti da particolari esigenze di celerità del procedimento, l'avvio del procedimento stesso è comunicato, con le modalità previste dall'articolo 8 , ai soggetti nei confronti dei quali il provvedimento finale è destinato a produrre effetti diretti ed a quelli che per legge debbono intervenirvi. Ove parimenti non sussistano le ragioni di impedimento predette, qualora da un provvedimento possa derivare un pregiudizio a soggetti individuati o facilmente individuabili, diversi dai suoi diretti destinatari, l'amministrazione è tenuta a fornire loro, con le stesse modalità, notizia dell'inizio del procedimento. 2. Nelle ipotesi di cui al comma 1 resta salva la facoltà dell'amministrazione di adottare, anche prima della effettuazione delle comunicazioni di cui al medesimo comma 1, provvedimenti cautelari.'; Article 10bis states '1. Nei procedimenti ad istanza di parte il responsabile del procedimento o l'autorità competente, 
More specifically, the European courts have consistently held that the right to be heard, as an essential component of the rights of defence, arises in all proceedings initiated against a person which are liable to culminate in an adverse measure against that person (Durande, Williams 2005).${ }^{9}$ In particular, Article 41 of the Charter of Fundamental Rights states that 'every person has the right to be heard before any individual measure which would affect him or her adversely is taken'.

The right to be heard consists of:

i) an obligation on the Commission to make its case known to the defendants;

ii) an obligation to grant the defendants an opportunity to submit their comments on the Commission's objections.

The first dimension implies that the defendant must have access to the Commission's file in order to respect the principle of equality of arms. ${ }^{10}$ Meanwhile, the second dimension of the right to be heard is the possibility for the defendant to make known his own views on the Commission's objections, whereby it does not matter, in principle, whether such submission is oral or written. ${ }^{11}$

prima della formale adozione di un provvedimento negativo, comunica tempestivamente agli istanti i motivi che ostano all'accoglimento della domanda. Entro il termine di dieci giorni dal ricevimento della comunicazione, gli istanti hanno il diritto di presentare per iscritto le loro osservazioni, eventualmente corredate da documenti. La comunicazione di cui al primo periodo interrompe i termini per concludere il procedimento che iniziano nuovamente a decorrere dalla data di presentazione delle osservazioni o, in mancanza, dalla scadenza del termine di cui al secondo periodo. Dell'eventuale mancato accoglimento di tali osservazioni è data ragione nella motivazione del provvedimento finale. Le disposizioni di cui al presente articolo non si applicano alle procedure concorsuali e ai procedimenti in materia previdenziale e assistenziale sorti a seguito di istanza di parte e gestiti dagli enti previdenziali. Non possono essere addotti tra i motivi che ostano all'accoglimento della domanda inadempienze o ritardi attribuibili all'amministrazione.'

9 See: judgment of the Court of First Instance of 30.09.2003, Joined Cases T-191/98 and T-212 to 214/98 Atlantic/Container Line v. Commission, ECLI:EU:T:2003:245.

10 ECtHR, Guide on Article 6 of the European convention on Human Rights, April 2019, p. 29, available at https://www.echr.coe.int/Documents/Guide_Art_6_criminal_ENG.pdf. It defines: 'Equality of arms is an inherent feature of a fair trial. It requires that each party be given a reasonable opportunity to present his case under conditions that do not place him at a disadvantage vis-à-vis his opponent. Equality of arms requires that a fair balance be struck between the parties, and applies to criminal and civil cases.'; European Commission, Commission notice on best practices for the conduct of proceedings concerning Articles 101 and 102 TFEU, par. 2.5.

11 Judgments of the European Court of Human Rights: of 11.06.1027, case no. 19867/12, Moreira Ferreira v. Portugal (no. 2), par. 67; of 24.03.2017, case no. 24221/13, Carmel Saliba v. Malta, par. 67. 


\section{Right to access the file}

Access to the Commission file is one of the procedural guarantees intended to apply the principle of equality of arms and to protect the right of defence.

The right of access to all files is provided for by different standards: Article 27 of Council Regulation (EC) No 1/2003; Article 15 of Commission Regulation (EC) No 773/2004; Article 18 of Council Regulation (EC) No 139/2004 and Article 17 of Commission Regulation (EC) No 802/2004. ${ }^{12}$ In particular, access to the file pursuant to the provisions mentioned above is intended to enable the effective exercise of the right of defence against the objections brought forward by the Commission. ${ }^{13}$

In fact, only persons, undertakings or associations of undertakings, to whom the Commission has addressed its objections, can request access to the documents. To be able to defend yourself adequately, these parties must be able to acquaint themselves with the information in the Commission's file, so that, on the basis of this information, they can effectively express their views on the preliminary conclusions reached by the Commission in its objections (Chiappanini 2012). ${ }^{14}$

Parties are allowed to access all documents of which the Commission case files are composed However, file access is not permitted under any circumstances to internal documents. These documents can be neither incriminating nor exculpatory, because they do not constitute part of the evidence on which the Commission can rely in its assessment of a case. Access to business secrets and other confidential information may be partially or totally restricted. The aim is to prohibit disclosure of information on the business activity, when information constitutes trade secrets. Examples of information that may qualify as business secrets include: technical and/or financial information relating to an undertaking's know-how, methods of assessing costs, production secrets and processes, supply sources, quantities produced and sold, market shares, customer and distributor lists, marketing plans, cost and price

12 Important in this context: Commission Notice on the rules for access to the Commission file in cases pursuant to Articles 81 and 82 of EC Treaty, Articles 53, 54 and 57 of EEA Agreement and Council regulation (EC) No 139/2004, (2005/C 325/07).

13 In Italy, the right of access to public administration documents is protected by Articles 22-24 of Law no. 241/1990.

14 Judgment of the Court of 08.06.1999, Case C-51/92P Hercules Chemicals NV/Commission, ECLI:EU:C:1999:357; judgment of the Court of 17.12.1999, Case C-185/95P Baustahlgewebe GmbH/Commission, ECLI:EU:C:1998:608; judgment of the Court of First Instance of 18.12.1992, Case T-10/92 Cimenteries CBR SA and others $v$ Commission of the European Communities, ECLI:EU:T:1992:123; order of the President of the Court of First Instance of 05.12.2001, Case T-216/01 R, Reisenbank AG / Commission, ECLI:EU:T:2001:277, par. 46-51; Judgment of the Court of First Instance of 18.12.1992, Joined Cases T-10/92, T-11/92, T-12/92 and T-15/92.R, Cimenteries CBR and Others/Commission, ECLI:EU:T:1992:123. 
structure and sales strategy. The category 'other confidential information' includes information other than business secrets, which may be considered as confidential, insofar as their disclosure would significantly harm a person or undertaking.

When business secrets are contained in the file, two opposite rights are to be protect: on the one hand, it must guarantee the right of access to the documents of the Commission for the parties to prepare their defence; on the other hand, the position of the company that could be damaged by access to company documents must be protected. In order to reconcile these two opposing rights, DG Competition has progressively introduced sophisticated access rules. First of all, the parties can submit a non-confidential version of the documents to the Commission, explaining the reasons for confidentiality. Alternatively, the party providing the data might either accept a negotiated disclosure or the data room procedure. In particular, data rooms are an exceptional tool which can safeguard the right of defence while respecting the legitimate interests of confidentiality of the undertakings or persons from which the Commission has obtained the information. By means of a data room, documents in the Commission's file are made accessible to an addressee of a Statement of Objections in a restricted manner, that is, by limiting the number and/or category of persons having access and the use of the information being accessed to the extent strictly necessary for the exercise of the rights of defence.

\section{Privilege against self-incrimination}

The privilege against self incrimination - nemo tenetur se detergere - is surely an indispensable bulwark of the right of an accused in any modern system of criminal justice. ${ }^{15}$ The issue concerning statements obtained by defying the will of an accused not to testify against himself, especially when they are subsequently deployed in criminal proceedings in support of the prosecution case, may be examined by the European Court of Human Rights under the second paragraph of Article 6 regarding the presumption of innocence or, which is more often the case, under the first paragraph of Article 6 (Michałek 2015, p. 275; Gardner, Ward 2003, p. 388). ${ }^{16}$

However, this privilege, which prevents the prosecution from obtaining evidence by defying the will of the accused not to testify against himself, plays

15 Judgment of the ECtHR of 17.10.2016, Case of international bank for commerce and development ad and others v. Bulgaria, par. 129.

16 The legal professional privilege is not expressly guaranteed in the Italian legal system, but it is included in Article 620 of the penal procedure code entitled 'Professional secret'. 
a significant role within competition law proceedings. ${ }^{17}$ It namely constitutes important grounds upon which the production and disclosure of documents as well as production of oral explications required under Article 20 of Regulation 1/2003 during the inspections may be resisted. But, as clarified in Tokai Carbon $^{18}$, the privilege against self-incrimination is only applicable in relation to documents which are directly self-incriminatory, while it cannot be claimed vis-a-vis other internal documents which might raise the culpability of the firm only indirectly. ${ }^{19}$

It is noteworthy that the right to silence may often overlap with the presumption of innocence (right to remain silent) protected under Article 6 paragraph 2 of the European Court of Human Rights. ${ }^{20}$

Regarding the procedure, the Communication of Commission Notice on best practices for the conduct of proceedings concerning Articles 101 and 102 TFEU in paragraph 2.5.2 establishes: 'Where the addressee of a request for information pursuant to Article 18 of Regulation (EC) No 1/2003 refuses to reply to a question in such a request invoking the privilege against self-incrimination [...] it may refer the matter in due time following the receipt of the request to the hearing officer, after having raised the matter with the Directorate-General for Competition before the expiry of the original time limit set.' (European Commission, Commission notice on best practices for the conduct of proceedings concerning Articles 101 and 102 TFEU, par. 2.5.2; Michałek 2015, p. 246; Kim, Levitt 2010, p. 1; McBride 2009, p. 4).

17 See e.g.: judgment of the Court of 29.06.2006, Case C-301/04 P Commission of the European Communities v SGL Carbon AG ECLI:EU:C:2006:432, which specifies that addressees of an Article 18 decision may be required to provide pre-existing documents, such as minutes of cartel meetings, even if those documents may incriminate the party providing them.

18 Judgment of the Court of 29.06.2006, Case C-301/04 P Commission of the European Communities v SGL Carbon AG ECLI:EU:C:2006:432, para. 41-42.

19 See judgments of the ECtHR of 08.02.1996 in case John Murray vs UK, Application No. 18731/91 and of 05.11.2002 in case Allan vs UK, Application No. 48539/99 in which the ECtHR stated that 'The right not to incriminate oneself is primarily concerned with respecting the will of the person to remain silent'.

20 About the right to remain silent and not to incriminate oneself, ECtHR, Guide on Article 6 of European Convention on Human Rights, supports that 'Anyone accused of a criminal offence has the right to remain silent and not to contribute to incriminating himself. Although not specifically mentioned in Article 6, the right to remain silent and the privilege against self-incrimination are generally recognised international standards which lie at the heart of the notion of a fair procedure under Article 6. By providing the accused with protection against improper compulsion by the authorities these immunities contribute to avoiding miscarriages of justice and to securing the aims of Article 6.' 


\section{Legal professional privilege}

Legal professional privilege (also referred to as 'LPP') constitutes another important component of the right to defence deriving from Article 6 European Court of Human Rights. ${ }^{21}$

In particular, certain communications between lawyer and client may, subject to strict conditions, be protected by legal professional privilege and thus be confidential as regards the Commission, as an exception to the latter's powers of investigation and examination of documents. The unfettered ability to communicate with a lawyer on a confidential basis is a fundamental right which exists in many legal systems around the world. It is undoubtedly crucial for a client to not be discouraged from telling her/his lawyer the whole truth concerning the case.

This privilege has to be respected from the preliminary inquiry stage. Indeed, LPP relates mostly to the investigative phase of the Competition Authorities' enforcement proceedings. First of all, the legal privilege prevents the Commission from examining and sizing such documents by the inspectors; it also ensures that the premises belonging to the lawyer are not searched by the Commission.

Regarding the proceeding, the company that invokes the legal privilege must provide adequate explanations to the Commission. ${ }^{22}$ After that, the Commission assesses whether the company has the benefit of confidentiality.

Going into details, the legal professional privilege is applicable in EU competition law to safeguard the confidentiality of written communications between the defendant and its lawyers. However, two cumulative conditions have to be satisfied: i) the communication should be "made for the purposes and

21 The exclusion of certain communications between lawyers and clients from the Commission's powers of enquiry derives from the general principles of law common to the laws of the Member States as clarified by the Court of Justice of the European Union: judgment of the Court of 18.05.1982, Case 155/79 AM\&S Europe Limited/Commission, ECLI:EU:C:1982:157; order of the Court of First Instance of 04.04.1990, Case T-30/89 Hilti/ Commission, ECLI:EU:T:1990:27; judgment of the Court of 17.09.2007, Joined Cases T-125/03 and T-253/03 Akzo Nobel Chemicals and Akcros Chemicals/Commission, ECLI:EU:T:2007:287, as confirmed by the Court in its judgment of 14.09.2010, Case C-550/07 P, Akzo Nobel Chemicals and Akcros Chemicals v Commission, ECLI:EU:C:2010:512.

The Court of Justice of the European Union has considered that the protection of the confidentiality of communications between a lawyer and a client is an essential corollary to the full exercise of the rights of defence. In any event, the principle of legal professional privilege does not prevent a lawyer's client from disclosing the written communications between them if the client considers that it is in his interest to do so.

22 European Commission, Commission notice on best practices for the conduct of proceedings concerning Articles 101 and 102 TFEU, par. 2.7. 
in the interest of the client's right of defence'; ii) the communication was made by 'independent lawyers' (Gippini-Fournier E. 2005), not linked to the client by any employment relationship. In this case, the documents and conversations between the client and the lawyer will be confidential. Otherwise, Commission officials may immediately read the contents of the document and take a copy of it, when it considers that the undertaking has: i) not substantiated its claim that the document concerned is covered by legal professional privilege; ii) has only invoked reasons that, according to the case law, cannot justify such protection; or iii) bases itself on factual assertions that are manifestly wrong.

Finally, if the undertaking has been unable to resolve the matter with the Directorate-General for Competition, based on paragraph 2.7 of 'Commission notice on best practices for the conduct of proceedings concerning Articles 101 and 102 TFEU': 'the hearing officer may be asked by undertakings or associations of undertakings to examine claims that a document required by the Commission in the exercise of Articles 18, 20 or 21 of Regulation (EC) No 1/2003 and which was withheld from the Commission is covered by legal professional privilege, within the meaning of the case law [...]'.

\section{Some perspectives for the transposition of the Directive - the Italian case}

The study showed that before the transposition of Directive 2019/1 the right of defence was not uniformly protected in all analyzed EU Member States. In particular, the right to be informed at the start of the procedure and access to the files of the proceedings are almost uniformly protected in the various European countries. Otherwise, Bulgaria, Croatia, Hungary, Poland, Slovakia and Romania do not protect in any way the right of defence as far as the privilege against self-incrimination and legal professional privilege.

This picture of non-uniformity regarding the protection of the right of defence risks remaining unchanged in light of the current content of Article 3 of Directive 2019/1.

In order to avoid this paradox, namely that NCAs enjoy the same powers and functions to protect competition law, but that the right of defence is not fully recognized toward the companies which are parties of the proceeding before the National Competition Authority, it is appropriate for Member States transposing Directive 2019/1 within two years, to comply with the standards of the European Commission's right of defence.

In conclusion, only in this way can the achievement of the objectives that have stimulated the adoption of Directive 2019/1 be ensured, otherwise there 
is a risk that nothing will change about the right of defence and that a vacuum of protection will remain in the countries of Eastern Europe. However, each Member State is free to ensure the right of defence in a greater way than that provided for by the Directive.

In Italian legislation, the right of defence is ensured by Article 24 of the Constitutional Charter, by the Law no. 241 of August $7^{\text {th }}, 1990$ (New rules on the administrative procedure), by the Law no. 287 of October $10^{\text {th }}, 1990$ (Competition and Fair Trading Act) and by the penal and procedural code.

But over the years a major role in the application of the right of defence has been played by the courts and scholars.

In particular, national legislation ensures the right of defence both during the antitrust procedure and in the following appeal proceedings.

Regarding the application of the right of defence (Art. 6, paragraph 1 ECHR), in the Italian legal system, it is important to mention the ruling of the European Court of Human Rights in the Menarini case. ${ }^{23}$

The facts are as follows.

In 2001, the AGCM, the independent regulatory authority in charge of competition, investigated an Italian applicant company for unfair competition. In a decision of April 2003 it fined the company six million euros for unfair competition on the market for diabetes diagnostic tests. All the company's appeals against that decision to the administrative court and to the Consiglio di Stato were rejected. The impugned penalty was not imposed by a court in adversarial proceedings but by the AGCM, an independent administrative authority. The applicant company had been able to challenge the penalty before the administrative court and to appeal against that court's decision to the Consiglio di Stato. According to the Court's case-law, these bodies met the standards of independence and impartiality required of a court. The administrative courts had examined the applicant company's various allegations, in fact and in law. ${ }^{24}$

The administrative courts had thus examined the evidence produced by the AGCM. The Consiglio di Stato has also pointed out that where the administrative authorities had discretionary powers, even if the administrative court did not have the power to substitute itself for an independent administrative authority, it was able to verify whether the administration had made proper use of its powers. As a result, the role of the administrative courts had not been limited simply to verifying lawfulness. They had been able to verify whether, in the particular circumstances of the case, the AGCM had made proper use of it powers.

23 Judgment of the ECtHR of 27.09.2011, case 43509/08 - A. Menarini Diagnostics Srl c. Italia.

24 See https://www.echr.coe.int/Documents/CLIN_2011_09_144_ENG_894208.pdf. 
The administrative courts were able to examine whether the decisions of the AGCM had been substantiated and proportionate, and even to check its technical findings. Moreover, the review was carried out by courts having full jurisdiction, in so far as the administrative court and the 'Consiglio di Stato' were able to verify that the penalty did fit the offence, and they could have changed it if necessary. In particular, the Consiglio di Stato, had gone beyond a 'formal' review of the logical coherency of the AGCM's reasoning and made a detailed analysis of the appropriateness of the penalty, having regard to the relevant parameters, including its proportionality. The decision of the AGCM had thus been reviewed by judicial bodies having full jurisdiction.

In conclusion, regarding the Italian legislation, the adoption of Directive $1 / 2019$ is a good opportunity to translate the principles made by Italian and European courts about the right of defence into national rules. In this context, ensuring the right of defence during competition proceedings is all the more important after the Directive, because NCAs of Member States will have more sanctioning powers. In fact, Article 10 of Directive 1/1029 states that Member States shall ensure that where NCAs find an infringement of Article 101 or 102 TFEU, they may by decision require the undertakings and associations of undertakings concerned to bring that infringement to an end. For that purpose, they may impose any behavioural or structural remedies which are proportionate to the infringement committed and necessary to bring the infringement effectively to an end. When choosing between two equally effective remedies, NCAs shall choose the remedy that is least burdensome for the undertaking, in line with the principle of proportionality.

\section{Literature}

Assonime (2017). I poteri delle autorità antitrust nazionali e le garanzie: verso la direttiva $\mathrm{ECN}+$ - Workshop Assonime - Associazione Antitrust Italia, Rome, November; (electronic resource) available at: http://www.assonime.it/_layouts/15/Assonime.Custom Action/GetPdfToUrl.aspx?PathPdf=http://www.assonime.it/attivita-editoriale/studi/ Documents/Note\%20e\%20Studi\%201-2018.pdf.

Bernatt M., Botta M., Svetlicinii A. (2018). The right of Defence in the Decentralized System of EU Competition Law Enforcement. A call for Harmonization from Central and Eastern Europe, World Competition, 41.

Botta M. (2018). The right of defence in ECN+ Directive, (electronic resource) available at: http://fcp.eui.eu/wp-content/uploads/sites/7/2019/02/2_BOTTA-seminar-ECN-13.8.2017. pdf.

Botta M., Svetlicinii A. (2015). The Right of Fair Trial in Competition Law Proceedings: Quo Vadis the Courts of the New EU Member States? in T. Skoczny, P. Nihoul (eds) Procedural Fairness in Competition Proceedings, Edward Elgar. 
Caragiale L. (2018). The competition enforcement design in the EU at crossroads, (electronic resource) http://fcp.eui.eu/wp-content/uploads/sites/7/2019/02/4_Presentation-Valentin-Mircea-FCP-15.09.2018.pdf.

Cengiz F. (2010). Multi-Level Governance in Competition Policy: the European Competition Network, European Law Review, Vol. 35.

Chiappanini A. (2012). The right of access to file in European competition proceedings and judicial protection, Diritto 24, 3 February 2012.

D'Alberti M., La rete europea delle autorità di concorrenza,(electronic resource) available at: http://www.learlab.it/Relazioni/D\%27Alberti.pdf.

Denkers M. (2018). ECN+ and the Dutch practice, A NCA perspective on ECN+, (electronic resource) available at: http://fcp.eui.eu/wp-content/uploads/sites/7/2019/02/5 Denkers_180915-Florence-ECN-and-the-Dutch-practice-1.pdf.

Durande S., Williams K. (2005). The practical impact of the exercise of the right to be heard: A special focus on the effect of Oral Hearings and the role of the Hearing Officers, Competition Policy Newsletter, 2, available at: ec.europa.eu/competition/ publications/2005, available at: http://ec.europa.eu/competition/publications/cpn/ 2005_2_22.pdf.

Gardner P., Ward T. (2003). The Privilege Against Self-Incrimination: In Search of Legal Certainty, European Human Rights Law Review, 4.

Gerber D.J. (2005). The Evolution of a European Competition Law Network, in C. Ehlermann, I. Atanasiu (eds.) Competition Law Annual 2002: Constructing the EU Network of Competition Authorities, Hart; available at: www.http://works.bepress.com/ david_gerber/46.

Ghezzi F., Marchetti B. (2017). La proposta di direttiva in materia di Rete europea della Concorrenza e la necessità di un giusto equilibrio tra efficienza e garanzie, Rivista italiana di Diritto Pubblico Comunitario, 5.

Gippini-Fournier E. (2005). Legal Privilege in Competition Proceedings before the European Commission: beyond the Cursory Glance, International Law Journal Fordham J. Int'l L., Vol. 28, Book 4, available at https://ssrn.com/abstract $=635963$.

Guerri E. (2005). Lapplicazione del diritto antitrust in Italia dopo il regolamento CE n. 1/2003, Giappichelli.

Kim S., Levitt M. (2010). Legal Professional Privilege Under European Union Law Navigating the Unresolved Questions Following the Akzo Judgment, Antitrust \& Trade Regulation Report, 99 ATRR 565, 11/05/2010.

McBride J. (2009). Human rights and criminal procedure The case law of the European Court of Human Rights, Council of Europe Publishing, Strasbourg 2009.

Michałek M. (2015). Right to defence in EU Competition law: the case of inspections, Warsaw.

Monti G. (2018). ECN Plus Directive: Empowering NCAs? Strengthening the Network?, European National Institute, (electronic resource) available at: http://fcp.eui.eu/ wp-content/uploads/sites/7/2019/02/1_Monti-FCP2018-ECN-plus.pdf.

Ortiz Blanco L. (2006). EC Competition Procedure, Oxford University Press.

Pace L.F. (2004). La politica di decentramento del diritto antitrust CE come principio organizzatore del regolamento 1/2003: luci ed ombre del nuovo regolamento di applicazione degli artt. 81 e 82 TCE, Rivista italiana di Diritto Pubblico Comunitario, 1.

Papp F.W. (2019). Directive of European Parliament and of the Council to empower the competition authorities of the Member States to be more effective enforcers and to 
ensure the proper functioning of the internal market ("ECN Directive"), Competition Policy International, 1; available at: https://www.competitionpolicyinternational.com/ directive-of-the-european-parliament-and-of-the-council-to-empower-the-competitionauthorities-of-the-member-states-to-be-more-effective-enforcers-and-to-ensure-theproper-functioning-of-the-internal/.

Parcu P.L. (2018). ECN + Directive Consequences for fines and Compliance Programmes, (electronic resource) available at: http://fcp.eui.eu/wp-content/uploads/sites/7/2019/02/3 Final_PARCU-ECN-plus-Directive-1-1.pdf.

Pera A., Pace V. (2003). The Modernisation of EC Competition Law and the Role of National Competition Authorities - Revolution or Evolution?, Il Diritto dell'Unione Europea, 2.

Brammer S. (2005). Concurrent Jurisdiction under Regulation 1/2003 and the Issue of Case Allocation, Common Market Law Review, Vol. 42, No. 5.

Torchia L. (2006). Il governo delle differenze. Il principio di equivalenza nell'ordinamento europeo, Bologna, 2006.

Türk A. (2006). Modernisation of EC Antitrust Enforcement, in H.C.H. Hofmann, A. Türk (eds), EU Administrative Governance, Edward Elgar Publishing.

Völcker S.B. (2004). Developments in EC Competition Law in 2003: An Overview, Common Market Law Review, Vol. 41, No. 4.

Wilks S. (2005). Agency Escape: Decentralization or Dominance of the European Commission in the Modernization of Competition Policy? Governance, 18(3).

Wils W.P.J. (2008). Efficiency and Justice in European Antitrust Enforcement, Hart.

Wils W.P.J. (2017). Competition Authorities: Towards more Independence and Prioritization? The European Commission's "ECN+" Proposal for a Directive to Empower the Competition Authority of the Member States to be more Effective Enforcers, Paris. 